\title{
Employing Solid Phase Microextraction as Extraction Tool for Pesticide Residues in Traditional Medicinal Plants
}

\author{
Thamani T. Gondo, ${ }^{1}$ Veronica C. Obuseng, ${ }^{1}$ Lesego C. Mmualefe, ${ }^{1,2}$ and Harriet Okatch ${ }^{1,3}$ \\ ${ }^{1}$ Chemistry Department, University of Botswana, Gaborone, Botswana \\ ${ }^{2}$ Botswana Institute for Technology Research and Innovation, Gaborone, Botswana \\ ${ }^{3}$ Perelman School of Medicine, University of Pennsylvania, Philadelphia, PA 19104, USA
}

Correspondence should be addressed to Veronica C. Obuseng; obusengv@mopipi.ub.bw

Received 12 February 2016; Accepted 12 July 2016

Academic Editor: Antonio V. Herrera-Herrera

Copyright (C) 2016 Thamani T. Gondo et al. This is an open access article distributed under the Creative Commons Attribution License, which permits unrestricted use, distribution, and reproduction in any medium, provided the original work is properly cited.

\begin{abstract}
HS-SPME was optimised using blank plant sample for analysis of organochlorine pesticides (OCPs) of varying polarities in selected medicinal plants obtained from northern part of Botswana, where OCPs such as DDT and endosulfan have been historically applied to control disease carrying vectors (mosquitos and tsetse fly). The optimised SPME parameters were used to isolate analytes from root samples of five medicinal plants obtained from Maun and Kasane, Botswana. The final analytes determination was done with a gas chromatograph equipped with GC-ECD and analyte was confirmed using electron ionisation mass spectrometer (GC-MS). Dieldrin was the only pesticide detected and confirmed with MS in the Terminalia sericea sample obtained from Kasane. The method was validated and the analyte recoveries ranged from $69.58 \pm 7.20$ to $113 \pm 15.44 \%$, with RSDs ranging from 1.19 to $17.97 \%$. The method indicated good linearity $\left(R^{2}>0.9900\right)$ in the range of 2 to $100 \mathrm{ng} \mathrm{g}^{-1}$. The method also proved to be sensitive with low limits of detection (LODs) ranging from $0.48 \pm 0.16$ to $1.50 \pm 0.50 \mathrm{ng} \mathrm{g}^{-1}$. It can be concluded that SPME was successfully utilized as a sampling and extraction tool for pesticides of diverse polarities in root samples of medicinal plants.
\end{abstract}

\section{Introduction}

The World Health Organization (WHO) has estimated that $80 \%$ of the global population relies on traditional medicine and about $51 \%$ of all the drug preparations in industrialized countries are derived from plant or synthesized based on plants extracts [1]. The recent increase in the use of medicinal plants may be due to the fact that they are cost effective as they are ubiquitous in nature when compared to pharmaceutical drugs. For example, Botswana is endowed with a large diversity of plants species which are claimed to have medicinal properties. These medicinal plants are sold in towns and research has indicated that street vendors use around 47 species of plants (distributed in 45 genera belonging to 29 families) to treat various diseases such as skin sores, sexually transmitted diseases, and asthma [2].

However, the safety and efficacy of using some of these medicinal plants have become a major issue $[3,4]$. There are various sources of contaminants of unprocessed medicinal plants, such as toxic metals, microorganisms and microbial toxins, radioactivity, fumigation agents, and pesticides $[5,6]$. Research on the safety of medicinal plants consumed by local people in Botswana is still limited. For example, Okatch et al. [7] assessed heavy metals content of some medicinal plants from Okavango Delta Region and found that the levels of heavy metals (arsenic, chromium, lead, and nickel) were below the WHO permissible levels. However, there is limited data on the identification and quantification of pesticide residues in medicinal plants used in Botswana.

Organochlorine pesticides such as DDT (dichlorodiphenyltrichloroethane) and endosulfan have been sprayed in the Okavango Delta in an attempt to control disease carrying vectors such as mosquitoes, from as early as the 1940s until the 1990s [8], when the less persistent pyrethroids such as deltamethrin and cypermethrin were introduced. Organochlorine pesticides have been banned (since mid-1970) in 
most countries due to their persistence in the environment, long range transport, bioaccumulation, and mammalian toxicity [9-12]. Many OCPs have been linked with a broad range of adverse human health and effects, including impaired reproduction, endocrine disruption, and immunesuppression, and they are also considered as carcinogenic substances [13]. Some of these OCPs (e.g., HCB (hexachlorobenzene), aldrin, endosulfan, and DDT and its metabolites) have been detected around Okavango Delta in different matrices such as water [14], sediments [15], and edible plants [16]. Pesticide residues in medicinal plants need to be determined to ensure that they do not exceed maximum recommended levels (MRLs).

Plants present complex matrices that may render trace analysis of pesticide residues quite challenging. Thus good extraction and highly sensitive detection techniques are required to isolate and quantify pesticides in these matrices. Sample preparation on the other hand is prone to errors and consumes about $80 \%$ of the analysis time [17]. Traditional extraction methods such as Soxhlet and liquid-liquid extraction have recently received less attention as they are lengthy and require multiple steps resulting in loss of analytes and errors in analysis $[17,18]$. For these reasons, recent trends in sample preparation are geared towards miniaturization, automation, high-throughput performance, on-line coupling with analytical instruments, and cost-effectiveness through extremely low or no solvent consumption [19]. Recent techniques for extraction and concentration of pesticides in various plants parts include solid phase extraction (SPE) [20]; quick, easy, cheap, effective, rugged, and safe (QuEChERS) [21]; solid phase microextraction (SPME) [16]; supercritical fluid extraction (SFE) [22]; matrix solid phase dispersion (MSPD) [23]; and pressurized liquid extraction (PLE) [24].

SPME has been utilized for extraction of OCPs from solid matrices because of its ability to preconcentrate analytes; it is solventless and applicable for both volatile and semivolatile analytes, as well as polar and nonpolar compounds [25]. The device affords minimal sample preparation steps accompanied by preconcentration, leading to increased sensitivity [26]. Matrices to which SPME has been employed include water [14, 27-31], soil [32-34], plants materials [16], milk [32], vegetables [35-37], fruits [38, 39], medicinal plants infusions $[40,41]$, and tea infusions [42-44]. In this work, HS-SPME was applied as a sampling and extraction tool for selected pesticides of varying polarity from selected medicinal plant parts (Pterocarpus angolensis, Maerua angolensis, Terminalia sericea, Cassia abbreviata, and Gymnosporia senegalensis) obtained from the Okavango Region, Botswana. The objectives of this study are to (i) optimize HS-SPME as a sample clean-up technique of solid samples of medicinal plants and develop a GC-ECD method for determination of organochlorines pesticides in plants and (ii) to apply the optimized method to determine pesticides in medicinal plants from Maun (Okavango Delta) and Kasane.

\section{Experimental}

2.1. Material. HPLC grade acetone (99.8\%) was obtained from Chromasolv, Sigma-Aldrich (Steinhem, Germany).
Pesticide standards, 4,4-DDT (1,1,1-trichloro-2,2-bis[p-chlorophenyl] ethane), $\beta$-endosulfan, $\alpha$-endosulfan, 4,4-DDE (1,1dichloro-2,2-bis[p-chlorophenyl]ethylene), aldrin, 4,4-DDD (1,1-dichloro-2,2-bis[p-chlorophenyl] ethane), o,p-DDT (1,1,1trichloro-2-(o-chlorophenyl)-2-(p-chlorophenyl) ethane), o,p-DDE (1,1-dichloro-2-(o-chlorophenyl)-2-(p-chlorophenyl)ethylene), hexachlorobenzene (HCB), dieldrin, heptachlor epoxide, $\alpha$-hexachlorocyclohexane $(\alpha-\mathrm{HCH}), \beta$-hexachlorocyclohexane $(\beta-\mathrm{HCH})$, endrin, PCB 52 (2,2,5,5-tetrachlorobiphenyl; internal standard 1), and PCB 153 (2,4,5,2,4,5hexachlorobiphenyl; internal standard 2), were all obtained from Sigma-Aldrich, Germany.

$15 \mathrm{~mL}$ SPME sampling vials, the sampling stand, SPME fiber $65 \mu \mathrm{m}$ divinylbenzene/polydimethylsiloxane (DVB/ PDMS), and fiber holders were all purchased from Supelco (Bellefonte, PA, USA).

Pesticide stock solutions $\left(1000 \mu \mathrm{g} \mathrm{L}^{-1}\right)$ were prepared by dissolving the individual pesticides in acetone. These stock solutions were stored at $4^{\circ} \mathrm{C}$ (for a maximum period of 3 months) and were used for the preparation of working standard mixtures.

\subsection{Chromatographic Analysis}

2.2.1. GC-ECD. Separation of organochlorine pesticides was achieved using a 7820A gas chromatograph (Agilent Technologies, Durban, South Africa). The system was equipped with a split/splitless injector and ${ }^{63} \mathrm{Ni}$ electron capture detector (ECD). An HP-5 MS (5\% phenyl methyl siloxane), fused silica capillary column $30 \mathrm{~m} \times 320 \mu \mathrm{m} \times 0.25 \mu \mathrm{m}$ (film thickness) manufactured by J\&W Scientific (Torrence, CA, USA) was employed in the separation of analytes. Ultrahigh purity nitrogen gas (99.999\%) was used as a carrier gas at a column head pressure of $20.114 \mathrm{Kpa}$ producing a flow rate of $0.5 \mathrm{~mL} / \mathrm{min}$. The injector and detector temperatures were set at $250^{\circ} \mathrm{C}$ and $300^{\circ} \mathrm{C}$, respectively. The oven temperature was programmed from an initial value of $70^{\circ} \mathrm{C}$ (held for $1 \mathrm{~min}$ ), ramped to $160^{\circ} \mathrm{C}$ at a rate of $40^{\circ} \mathrm{C} / \mathrm{min}$ (held for $0.5 \mathrm{~min}$ ), ramped to $180^{\circ} \mathrm{C}$ at a rate of $35^{\circ} \mathrm{C} / \mathrm{min}$ (held for $1 \mathrm{~min}$ ), ramped to $240^{\circ} \mathrm{C}$ at a rate of $4^{\circ} \mathrm{C} / \mathrm{min}$ (held for $2 \mathrm{~min}$ ), and ultimately ramped to $270^{\circ} \mathrm{C}$ at a rate of $5^{\circ} \mathrm{C} / \mathrm{min}$ (held for $2 \mathrm{~min})$. The injection volume was $2 \mu \mathrm{L}$ in the splitless mode.

2.2.2. GC-MS. Confirmation of the pesticides was performed on a 5975C gas chromatography mass selective detector (GC/MSD) system (Agilent Technologies, Santa Clara, USA), with triple-axis high energy dynode-electron multiplier (HED-EM) detector (Agilent Technologies, USA). The GC column and conditions were the same as for GC-ECD analyses as described in the previous section. Helium was used as the carrier gas at a flow rate of $0.5 \mathrm{~mL} / \mathrm{min}$. The injector and ion source temperatures were kept at $230^{\circ} \mathrm{C}$ while the transfer line was kept at $280^{\circ} \mathrm{C}$. Full scan $(\mathrm{m} / z$ 50-600) GC/MS acquisition was carried out at $1 \mathrm{scan} \mathrm{sec}^{-1}$. The detector was operated in the electron ionization (EI) mode $(70 \mathrm{eV})$, with an ionization filament emission current of $400 \mu \mathrm{A}$. A solvent delay of $4 \mathrm{~min}$ was set for the MS to avoid damaging the filament. The mass spectra obtained were compared to the NIST/EPA/NIH Mass Spectral Library, Version 2.0 


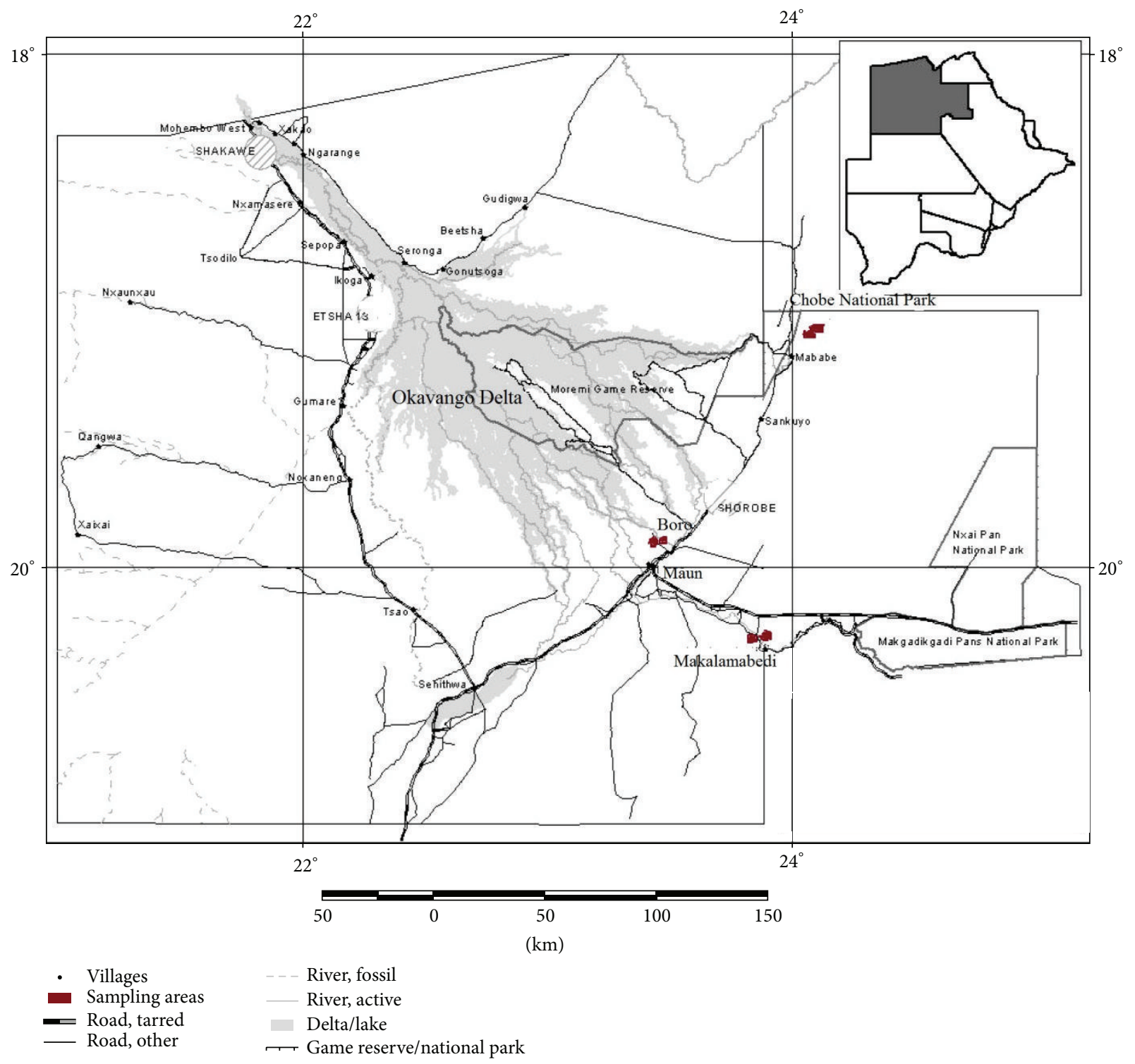

FIGURE 1: Map of Okavango Delta (Maun) and Kasane areas in Botswana showing the sampling sites.

(Gaithersburg, MD, USA) through Automated Mass Spectral Deconvolution and Identification System (AMDIS) developed by the National Institute for Standards and Technology (NIST) Spectral Library Search. The identities of compounds were also confirmed by comparing their mass spectra with the spectra of the standards and spectra in the NIIST Library and further confirmation (for isomers) was based on comparing the retention times with those obtained for the respective standards.

2.3. Sampling and Sample Pretreatment. Medicinal plant specimens (roots parts) were collected in the month of July 2012 from Ngamiland District in the northern part of Botswana (Figure 1). Samples were collected from three different sites, which are as follows: Makalamabedi, situated $56 \mathrm{~km}$ south of Maun, along the Boro River, and around Chobe National Park which is situated near Kasane.
Medicinal plants were selected based on the interview with traditional healers in the northern part of Botswana who gave information on medicinal plants and the parts used, preparation of remedies, and diseases treated. The plants were collected randomly as the team surveyed and identified the plants in the study areas. The collected samples were wrapped in aluminium foil and then placed in sealed plastic bags stored in ice prior to transporting. The five selected medicinal plants are Pterocarpus angolensis, Maerua angolensis, Terminalia sericea, Cassia abbreviata, and Gymnosporia senegalensis. The samples were obtained from Okavango Delta except Pterocarpus angolensis and another sample of Terminalia sericea, which was obtained from Kasane (Chobe). Two Terminalia sericea species were obtained from different locations and both plants were analysed to compare the levels of pesticides in those areas. The species were labelled as Terminalia sericea A (Okavango Delta, Maun; 
Figure 1) and Terminalia sericea B (Kasane, Chobe). Plant roots samples were dried at room temperature for 24 hours and then cut into small pieces with a clean knife. Dried roots samples were coarsely ground using a pestle and mortar and passed through a $500 \mu \mathrm{m}$ sieve. These were kept in a dark cold room $\left(4^{\circ} \mathrm{C}\right)$ and analysed within a period of four months.

\subsection{Optimisation of SPME Parameters. A $65 \mu \mathrm{m}$ PDMS/} DVD (medium polarity) was chosen as it is capable of extracting relatively nonpolar to midpolar OCPs $[14,16,33]$. The SPME fiber was conditioned by inserting the fiber into the GC injection port for 1 hour at the $250^{\circ} \mathrm{C}$ and oven temperature of $200^{\circ} \mathrm{C}$ while the electron capture detector temperature was set at $300^{\circ} \mathrm{C}$. The fiber was inserted into another GC injection port for a further $4 \mathrm{~min}$ at $250^{\circ} \mathrm{C}$ after each and every run as a way of cleaning the fiber to minimise errors as a result of run-to-run carryovers.

(i) Extraction Temperature. Optimum extraction temperature was determined by varying temperature between 50 and $100^{\circ} \mathrm{C}$ for $30 \mathrm{~min} .2 .5 \mathrm{~g}$ selected blank solid plant samples which were collected in area without any history of pesticides use (dry and prescreened for pesticide residues) were weighed and placed in a $15 \mathrm{~mL}$ vial, and $125 \mu \mathrm{L}$ of the standard mixture was added to the sample, shaken for $5 \mathrm{~min}$, and then further kept in the dark for 2 hours. This was followed by the addition of $2.5 \mathrm{~mL}$ of water. The $65 \mu \mathrm{m}$ PDMS/DVB fiber was exposed to headspace to allow adsorption of analytes onto the fiber.

(ii) Extraction Time. Extraction time was determined by weighing $2.5 \mathrm{~g}$ dried blank solid plant sample in a $15 \mathrm{~mL}$ vial, followed by addition of $125 \mu \mathrm{L}$ of the standard pesticide mixture before shaking for 5 min that was then further kept in the dark for 2 hours and then adding $2.5 \mathrm{~mL}$ of water. The $65 \mu \mathrm{m}$ PDMS/DVB fiber was inserted into the vial and exposed to the headspace. The extraction procedure was repeated at 10-minute interval between 20 and $50 \mathrm{~min}$.

(iii) Phase Ratio. Phase ratio was investigated by increasing the mass of the homogenised blank sample from 5 to $10 \mathrm{~g}$ (i.e., 5, 7.5, 10, and $11.5 \mathrm{~g}$ ). Each mass was spiked with a concentration of $50 \mathrm{ng} \mathrm{g}^{-1}$ by using a spike level of $1000 \mu \mathrm{g} \mathrm{L}^{-1}$ standard mixture and then kept in the dark for 2 hours. The analytes were adsorbed onto the $65 \mu \mathrm{m}$ PDMS/DVB fiber for $40 \mathrm{~min}$ at $90^{\circ} \mathrm{C}$ and then desorbed onto the GC column.

(iv) Volume of Water (Homogenisation). The amount of water added to the dry blank plant sample was also optimised by adding different amounts of water ranging from 1.25, 2.5, 5, and $7.5 \mathrm{~mL}$ to $2.5 \mathrm{~g}$ of dried plant sample after adding $125 \mu \mathrm{L}$ of $1000 \mu \mathrm{gL}^{-1}$ standard mixture. The sample was shaken for $5 \mathrm{~min}$ and vial was heated to $90^{\circ} \mathrm{C}$ and then a $65 \mu \mathrm{m}$ PDMS/DVB fiber was exposed to the headspace for $40 \mathrm{~min}$ and then desorbed at $250^{\circ} \mathrm{C}$ on the injection port.

(v) Desorption Time. $125 \mu \mathrm{L}$ of $1000 \mu \mathrm{g} \mathrm{L}^{-1}$ standard mixture and $5 \mathrm{~mL}$ of water were added to $2.5 \mathrm{~g}$ of dried blank plant sample to optimise desorption time at three different times $(3,5$, and $7 \mathrm{~min})$.
During optimisation, desorption temperature was kept at $250^{\circ} \mathrm{C}$ in each case and each study was done in triplicate.

2.5. Analytical Parameters. Analytical parameters such as limit of detection (LOD), limit of quantification (LOQ), linearity, accuracy (recoveries), and precision (repeatability) were studied.

Linearity was investigated using a 5-point matrix matched calibration, which ranged from 2 to $100 \mathrm{ng} \mathrm{g}^{-1}$. LOD and LOQ were calculated based on signal to noise ratio $(\mathrm{S} / \mathrm{N})$ of 3 and 10 , respectively, after spiking seven matrix blanks with low concentration of standards $\left(2 \mathrm{ng} \mathrm{g}^{-1}\right)$. Recoveries were accessed over 4 concentrations $\left(7,25,40\right.$, and $\left.70 \mathrm{ng} \mathrm{g}^{-1}\right)$ on blank matrices which were found to be pesticide free or undetectable levels of pesticides. The above four concentrations were measured in four replicates and precision was determined in terms of relative standard deviations (RSDs). The precision was also monitored by running a $50 \mathrm{ng} \mathrm{g}^{-1}$ spiked blank sample in seven different days (within a week) to check the variation between different days (interday precision). A $50 \mathrm{ng} \mathrm{g}^{-1}$ spiked blank was also run for seven times (1 day) to determine the intraday precision. Two internal standards of PCB 52 and PCB 153 were utilised to reduce variations during quantification.

2.6. Application of the Developed Method on Real Samples. Pesticides were quantified in five selected medicinal plants used by traditional doctors. Quantification was done using matrix matched calibration curve to compensate for matrix effect. The optimised SPME conditions were used for extraction of pesticides in the five medicinal plants, following analysis by GC.

\section{Results and Discussion}

\subsection{Optimisation of SPME Conditions}

3.1.1. Effect of Extraction Temperature. Effect of extraction temperature was studied in the range of 50 to $100^{\circ} \mathrm{C}$. Generally an increase in temperature resulted in increased diffusion of analytes from the sample to the headspace due to the volatility of the analytes (Figures 2(a) and 2(b)). It was also observed that extraction efficiencies increased with temperature up to $90^{\circ} \mathrm{C}$ and eventually decreased at temperatures of $100^{\circ} \mathrm{C}$ for compounds with molecular weight ranging from 318 to $406 \mathrm{~g} \mathrm{~mol}^{-1}$ (aldrin, dieldrin, endrin, heptachlor epoxide, $\alpha$-endosulfan, and $\beta$-endosulfan; $\mathrm{p}, \mathrm{p}$ DDT, p,p-DDE, p,p-DDD, o,p-DDT, and o,p-DDE; Figure $2(\mathrm{~b}))$, except for $\mathrm{HCB}, \alpha-\mathrm{HCH}$, and $\beta-\mathrm{HCH}$ as shown in Figure 2(a). The decrease in extraction efficiencies at higher temperatures might be due to the exothermic nature of the fiber as observed by Doong and Liao [33]. Moreover, higher temperatures increase the solubility of the target analytes in water, hence reducing their distribution coefficients and resulting in decreased extraction efficiencies. In general, compounds with lower molecular weights such as HCB $\left(284.8 \mathrm{~g} \mathrm{~mol}^{-1}, 323-326^{\circ} \mathrm{C}\right), \alpha-\mathrm{HCH}\left(290.8 \mathrm{~g} \mathrm{~mol}^{-1}, 288^{\circ} \mathrm{C}\right)$, and $\beta-\mathrm{HCH}\left(290.8 \mathrm{~g} \mathrm{~mol}^{-1}, 288^{\circ} \mathrm{C}\right)$ enter their gas phase 


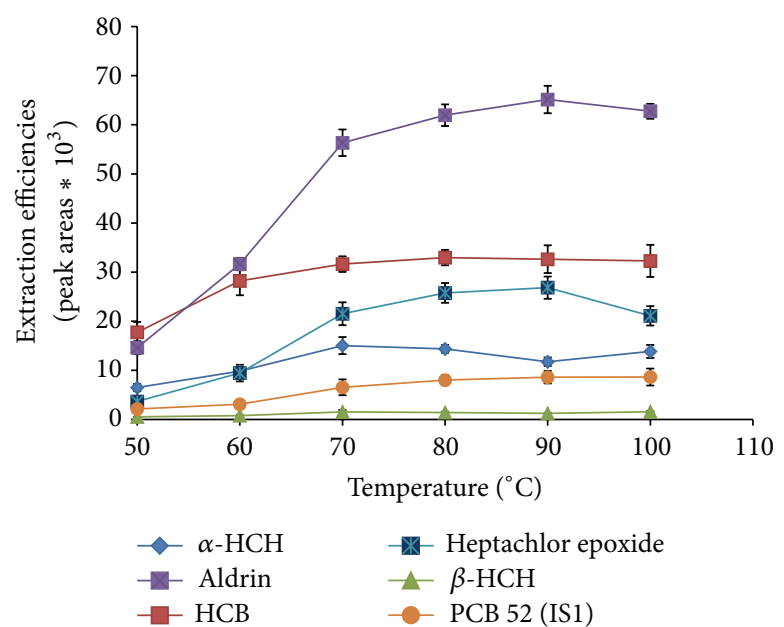

(a) Low molecular weight pesticides

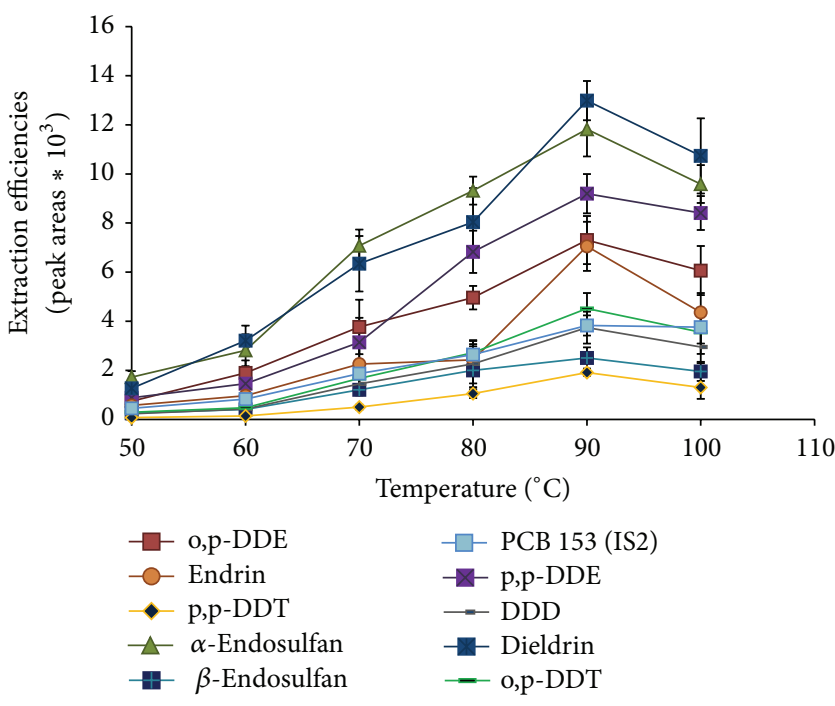

(b) High molecular weight pesticides

FiguRE 2: Extraction efficiencies of 14 selected organochlorine pesticides from $50 \mathrm{ng} \mathrm{g}^{-1}$ spiked plant root samples, at various temperatures.

more easily than compounds with higher molecular weights. Analysis of variance (ANOVA) was employed to ascertain the difference in extraction efficiencies at temperatures 70 to $100^{\circ} \mathrm{C}$ and the results indicated no statistically significant differences in the extraction efficiencies $\left(F_{\text {calc }}<F_{\text {critical }}\right.$, at $95 \%$ confidence level). A temperature of $90^{\circ} \mathrm{C}$ was selected as the optimum extraction temperature for every pesticide since most pesticides indicated high sensitivity at this temperature.

3.1.2. Effect of Extraction Time. In SPME, equilibrium is reached when the analytes adsorbed by the fiber coating are independent of further increase in extraction time. The time required for reaching equilibrium between the fiber and the vapour phase was determined. Figure 3 shows that most of the analysed pesticides reached the highest extraction efficiencies at $40 \mathrm{~min}$. $\beta-\mathrm{HCH}$ was extracted efficiently within a shorter period of time $(30 \mathrm{~min})$ due to its low boiling point and partition coefficient $\left(\log K_{\text {ow }} ; 3.78\right)$. However, one isomer of lindane (i.e., $\alpha-\mathrm{HCH}$ ) did not indicate a significant change from 30 to $50 \mathrm{~min}$ as the graph was almost level in that region (this was also proved by ANOVA test). All lindane isomers have relatively low values of $\log K_{\text {ow }}$ and they exhibit the shortest equilibrium time. HCB indicated a significant drop in extraction efficiencies after an extraction time of $40 \mathrm{~min}$. This could possibly be due to its high volatility resulting in its loss. The graph was almost level after $40 \mathrm{~min}$ for all other pesticides in Figure 3 (except HCB and aldrin). It could be that possibly the fiber had reached its maximum loading capacity; thus, the amount of analytes adsorbed was independent of increase in time. Despite some compounds showing extraction times higher than $40 \mathrm{~min}$ (i.e., aldrin, heptachlor epoxide, $\alpha$-endosulfan, p,p-DDD, and endrin), the $t$-test $(P$ value $=0.05,95 \%$ confidence level $)$ indicated that there was no statistically significant difference; therefore, 40 min was chosen as the optimum extraction time for all the

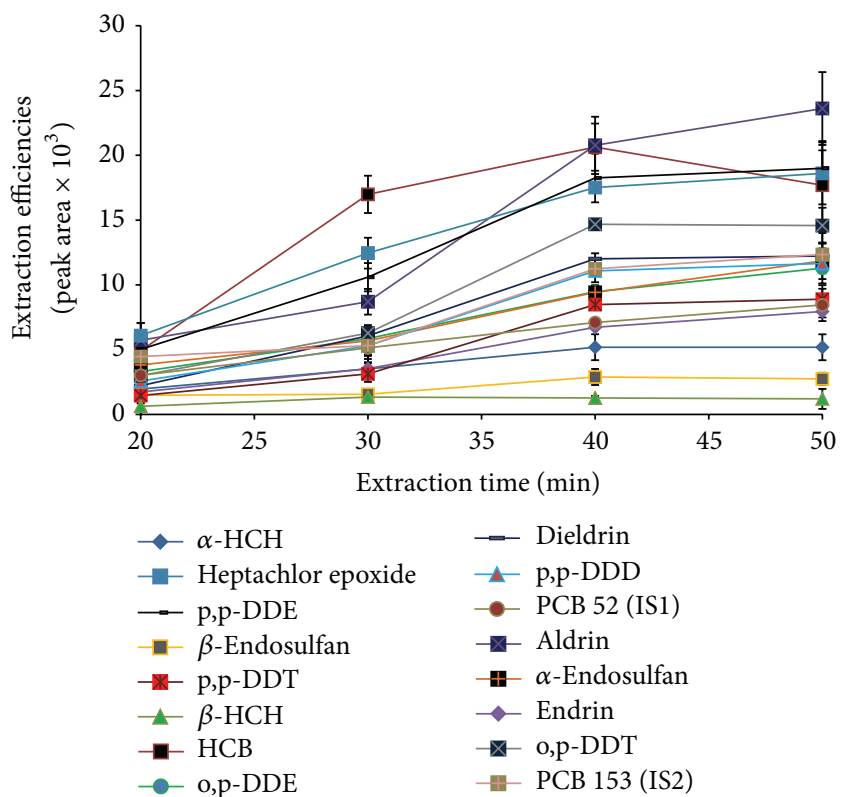

FIGURE 3: Effect of extraction time on extraction efficiencies (peak areas) of analytes determined using a $50 \mathrm{ng} \mathrm{g}^{-1}$ spiked root sample.

analytes. It should also be noted that a shorter extraction time is crucial in analysis to increase sample throughput.

3.1.3. Phase Ratio. Phase ratio in this work is defined as the ratio of mass of the solid sample to the volume of the headspace in the vial. The phase ratio was altered by increasing the mass of the homogenized sample in a $15 \mathrm{~mL}$ vial, thus altering the headspace volume. Many pesticides showed a drop in extraction efficiencies after a phase ratio of $1: 1 \mathrm{~m} / \mathrm{v}$, whereas the extraction efficiencies of endrin, $\beta$ endosulfan, p,p-DDD, o,p-DDT, and p,p-DDT reduced at a 


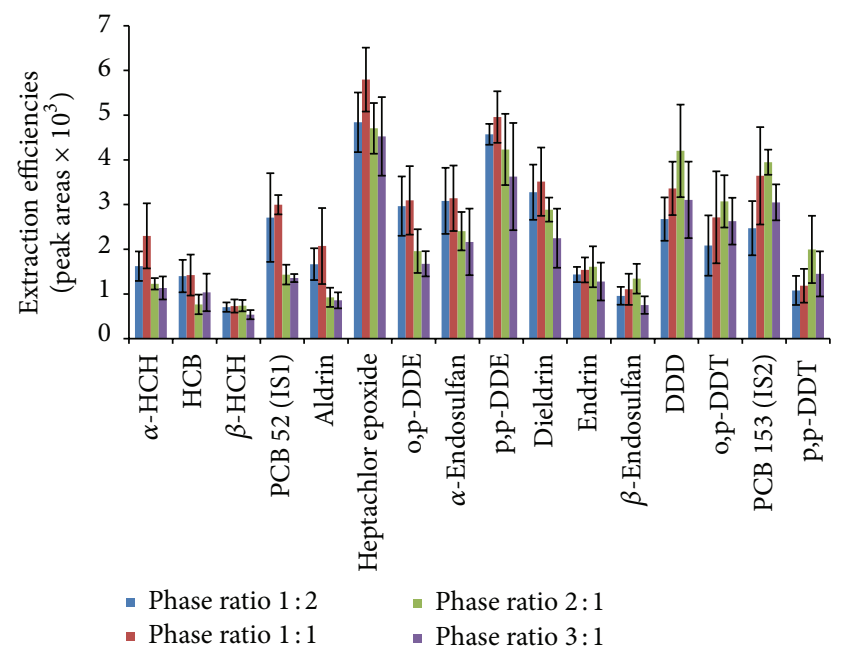

FIGURE 4: Effect of phase ratio on the extraction efficiencies of analytes.

phase ratio of $3: 1 \mathrm{~m} / \mathrm{v}$ (Figure 4). These compounds have higher molecular masses and lower vapour pressure, ranging from magnitudes of $10^{-6}$ to $10^{-7} \mathrm{mmHg}$. Their low vapour pressures imply that they do not vaporize easily; hence a high phase ratio is needed to increase their concentration in the headspace. On the other hand, compounds which gave maximum response at a phase ratio 1:1 (as shown in Figure 4) have lower molecular masses and higher vapour pressure in the range of $10^{-4}$ to $10^{-5} \mathrm{mmHg}$. The low response at lower phase ratio could be due to insufficient equilibration time since in this case a significant portion of the analytes has to be transported to the fiber from the sample and also mass transfer of analytes into the bulk of the fiber represents a slow step in the overall process [45]. A phase ratio of $1: 1 \mathrm{~m} / \mathrm{v}$ was selected for this study since most pesticides gave better extraction efficiencies at this ratio.

3.1.4. Sample Homogenisation. Solid samples are ground into finer particles and water is added to facilitate analyte transfer from the sample matrix into the headspace when performing HS-SPME experiments [33]. This also promotes repeatability in measurements [44]. Water has the ability to open pores in the matrix and also to increase the surface area to enable release of analytes from the matrix. Figure 5 shows that extraction efficiencies for most pesticides increased when the water volume was increased in the sample up to $5 \mathrm{~mL}$ followed by a decrease as the water content was increased.

All these compounds (i.e., heptachlor epoxide, o,p-DDE, $\alpha$-endosulfan, p,p-DDE, dieldrin, endrin, $\beta$-endosulfan, $\mathrm{p}, \mathrm{p}$ DDD, o,p-DDT, and p,p-DDT) are characterized by low water solubility and their vapour pressures are quite lower than those of lindane compounds. However, HCB and aldrin indicate a decrease in extraction efficiencies after water amount was increased to $5 \mathrm{~mL}$. These compounds have low water solubility when compared to $\alpha-\mathrm{HCH}$ and $\beta-\mathrm{HCH}$ and are also characterized by high vapour pressure compared to all compounds which indicated drop in extraction efficiencies at $7.5 \mathrm{~mL}$. It is therefore assumed that increasing the

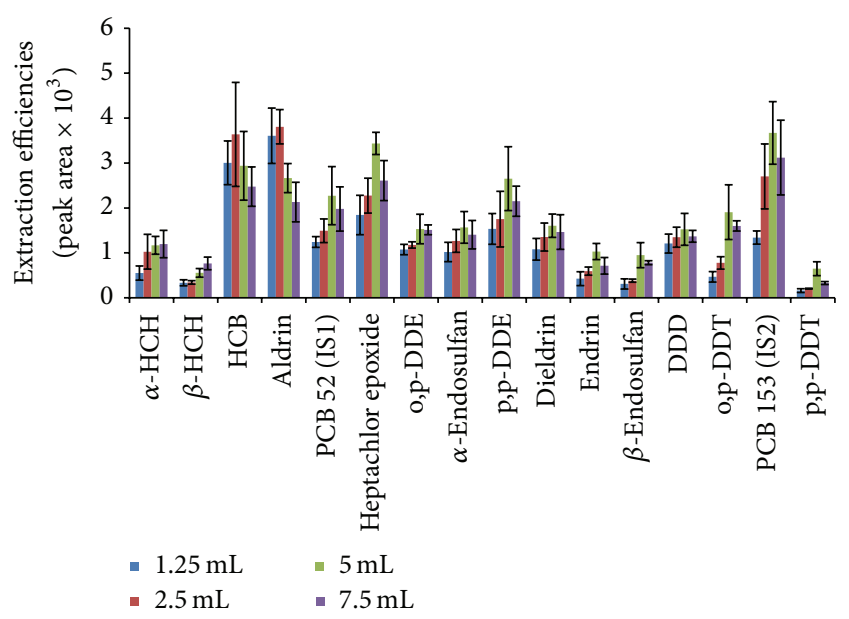

FIGURE 5: Effect of amount of water added to sample on extraction efficiencies of organochlorine pesticides.

water amount will easily limit their diffusion to the fiber due to increased water vapours in the headspace. It has been reported that relative humidity of $90 \%$ can reduce the adsorption by about $10 \%$ [46]. The extraction efficiencies of the two isomers of lindane $(\alpha-\mathrm{HCH}$ and $\beta-\mathrm{HCH})$ increased as water was increased up to $7.5 \mathrm{~mL}$. Lindane compounds are known to be more soluble in water, with low partition coefficients $\left(\log K_{\text {ow }}\right.$ is 3.80 and 3.78 for $\alpha-\mathrm{HCH}$ and $\beta$ $\mathrm{HCH}$, resp.). The increase in extraction efficiencies might be caused by the type of fiber used, that is, $65 \mu \mathrm{m}$ PDMS-DVB fiber, since these analytes are partitioned more readily in this fiber as compared to other compounds. Doong and Liao [33] reported a significant increase in extraction efficiencies with a $65 \mu \mathrm{m}$ PDMS-DVB fiber for extraction of $\mathrm{HCH}$ compounds from the soil. Water soluble compounds are easily released from the matrix into water, making these analytes more available for extraction [46]. Furthermore, the high vapour pressure of $\alpha-\mathrm{HCH}$ and $\beta-\mathrm{HCH}$ causes them to be more partitioned into the headspace than in the aqueous solution. However, too much water is detrimental to analyte extraction into the headspace. In this work, $5 \mathrm{~mL}$ was selected as the optimum since many compounds indicated high efficiencies at that level.

3.1.5. Desorption Time. Desorption time influences the number of molecules desorbed into the injector port. Longer desorption time will completely desorb the analytes, but it is also avoided since it can damage the fiber. An increase in extraction efficiencies was observed as desorption time was varied between 3, 5, and $7 \mathrm{~min}$. Desorption time can be influenced by several factors such as the thickness of the fiber, the boiling point of the analyte, desorption temperature, and the partition constant of the analytes. The analytes heptachlor epoxide, o,p-DDE, $\alpha$-endosulfan, endrin, o,pDDT, p,p-DDD, and p,p-DDT indicated an increase from 3 to $5 \mathrm{~min}$ and a drop in extraction efficiencies at $7 \mathrm{~min}$ (Figure 6). The drop in extraction efficiencies might indicate complete desorption of particular analytes. Only $\alpha-\mathrm{HCH}$, $\mathrm{HCB}, \beta-\mathrm{HCB}$, aldrin, $\mathrm{p}, \mathrm{p}-\mathrm{DDE}, \beta$-endosulfan, and dieldrin 


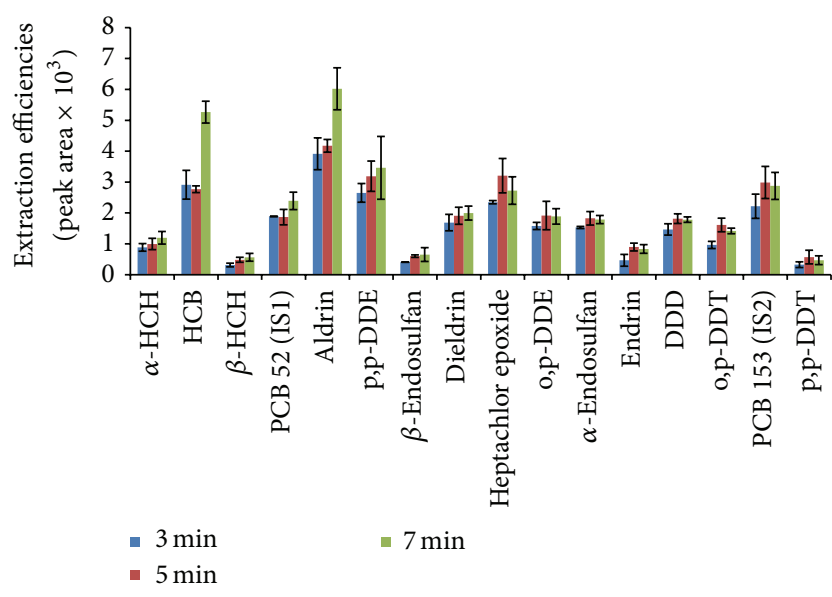

FIGURE 6: Effect of desorption time of 14 organochlorine pesticides on their extraction efficiencies.

indicated slightly higher peak areas at 7 min desorption time (Figure 6). However, the more volatile compounds such as $\alpha-\mathrm{HCH}, \mathrm{HCB}, \beta-\mathrm{HCB}$, and aldrin were expected to give less desorption time, but the reverse occurred. It was also discovered that early eluting compounds $(\alpha-\mathrm{HCH}$, $\mathrm{HCB}, \beta-\mathrm{HCB}$, and aldrin) are coextracted with some volatile matrix components, which could result in increase in their peak areas, leading to errors. The increase in extraction efficiencies of $\mathrm{p}, \mathrm{p}$-DDE might be due to degradation of $\mathrm{p}, \mathrm{p}$ DDT on a hot GC inlet surface which is similar to what was observed by other authors [47]. Longer desorption time for $\beta$-endosulfan and dieldrin might be due to their high molecular weights (relatively high boiling points) and low vapour pressure. On carrying out $t$-test statistics $(P=0.05$, $95 \%$ confidence level), it shows that there was no statistical significant difference between $5 \mathrm{~min}$ and $7 \mathrm{~min}$ for every pesticide under study. Nevertheless, no significant difference was observed between 3 and 5 min for most pesticides, except for heptachlor epoxide, endrin, and o,p-DDT. A desorption time of $5 \mathrm{~min}$ was selected for this study since there was no significant increase in extraction efficiencies after $5 \mathrm{~min}$.

3.2. Performance of the SPME Method. Validation of SPMEGC-ECD was applied on spiked blanks which were previously screened and no pesticide was detected.

3.2.1. Recoveries (Accuracy). Average recoveries were found to range from $69.58 \pm 7.20 \%$ ( $\beta$-endosulfan) to $113.92 \pm 15.44 \%$ $(\beta-\mathrm{HCH})$ as shown in Table 1 . Low recoveries were observed at lower analyte concentrations for each of the analytes; for example, for $7 \mathrm{ngg}^{-1}$, the lowest recoveries were $69.58 \pm$ $7.20 \%$ and for concentrations of $25 \mathrm{ng} \mathrm{g}^{-1}$ and $40 \mathrm{ng} \mathrm{g}^{-1}$ the lowest recoveries were found to range from $89.66 \pm 7.54$ to $86.46 \pm 3.95 \%$. Most compounds indicated improvement in recoveries at higher concentrations; $70 \mathrm{ngg}^{-1}$ showed recoveries range of $89.59 \pm 10.21$ to $113.92 \pm 15.44 \%$. $\beta$ $\mathrm{HCH}$ indicated the highest recoveries at high concentration $\left(70 \mathrm{ng} \mathrm{g}^{-1}\right)$ when compared to all the OCPs. The results might be influenced by the selectivity of the SPME fiber used. The
PDMS-DVB fiber has been found to be selective to aromatic hydrocarbons and some small volatile analytes [33], hence high recoveries for $\beta-\mathrm{HCH}$ and $\alpha-\mathrm{HCH}$. However, most OCPs indicated high recoveries when PDMS-DVB was used, that is, $\geq 70 \%$; and the fiber also showed a good affinity to the compounds containing phenyl groups such as DDT, DDE, p,p-DDD, and HCB. It was noted that some analytes showed recoveries above $100 \%$. We cannot be absolute on the causes of that; however, these can be due to matrix effects as solid samples are generally difficult to homogenise (especially after spiking), which might result in nonequilibration between the three phases, hence the use of matrix matched standards. These errors are negligible since they were all lower than $20 \%$. In addition the EPA allows recoveries to range from 70 to $120 \%$ for a method, thus taking into consideration the analytical errors.

3.2.2. Method Precision. The ranges of RSD were found to be from 5.64 to $17.97 \%, 5.31$ to $13.02 \%, 3.43$ to $12.97 \%$, and 1.19 to $13.04 \%$ for concentrations of $7 \mathrm{ng} \mathrm{g}^{-1}, 25 \mathrm{ng} \mathrm{g}^{-1}$, $40 \mathrm{ng} \mathrm{g}^{-1}$, and $70 \mathrm{ng} \mathrm{g}^{-1}$, respectively (Table 1). The intra- and interday precision calculated using a $5 \mathrm{ng} \mathrm{g}^{-1}$ spiked standard were found to range from 5.41 to $11.87 \%$ and from 5.76 to $15.79 \%$, respectively. It can be noted that better precision was obtained for higher concentrations compared to the lower concentrations. In general, the RSDs were lower than 20\% in all cases, indicating low variability between measurements. This result was comparable with other studies; for instance, repeatability ranging from 3.2 to $11.3 \%$ was reported for analysis of OCPs in textiles using SPME [48]. In another study, low RSDs were obtained for analysis of OCPs in water, ranging from 5.2 to $14.0 \%$ [14]. Fidalgo-Used and coworkers reported repeatability in terms of RSD, in the range of 6 to $28 \%$ when SPME was used for OCPs analysis in fish samples [49]. In another study, repeatability for analysis of organochlorines in the soil using SPME was reported to range from 3.2 to $26.3 \%$ [33]. Schurek and coworkers [44] also analysed a wide range of pesticides in tea using SPME and obtained repeatability in the range of 2 to $24 \%$, in terms of RSD. Therefore, results were in agreement with other authors' findings.

3.2.3. Linearity. The linearity of the method was tested with matrix matched standards spiked at different concentrations, ranging from 2 to $100 \mathrm{ng} \mathrm{g}^{-1}$ (i.e., 2, 10, 25, 50, and $100 \mathrm{ng} \mathrm{g}^{-1}$ ). Good linearity was found for all the analytes with correlation coefficients $\left(R^{2}\right)$ greater than 0.99 when matrix matched standards were used for calibration. The results are shown in Table 2. The observations are in agreement with the results by other researchers when extracting OCPs using SPME from different matrices, for example, cotton samples [48] and water samples $[30,50]$, which all indicated good $R^{2}$ (i.e., greater than 0.99 for most analytes).

3.2.4. Detection Limits. The LODs (limits of detection) and LOQs (limits of quantification) were investigated and the results are shown in Table 2 . It should be noted that the detection limits determined here were method detection 
TABLE 1: \% recoveries and their standard deviations (mean \pm SD) after analysis of spiked blank samples. The precision of the method calculated as \% RSD for four measurements of each sample.

\begin{tabular}{|c|c|c|c|c|c|c|c|c|}
\hline & \multicolumn{8}{|c|}{ Mean recoveries } \\
\hline & $7 \mathrm{ng} \mathrm{g}^{-1}$ & $\%$ RSD & $25 \mathrm{ng} \mathrm{g}^{-1}$ & RSD & $40 \mathrm{ng} \mathrm{g}^{-1}$ & RSD & $70 \mathrm{ng} \mathrm{g}^{-1}$ & RSD \\
\hline$\alpha-\mathrm{HCH}$ & $90.87 \pm 6.26$ & 6.89 & $91.46 \pm 8.06$ & 8.82 & $92.07 \pm 10.72$ & 11.64 & $94.47 \pm 3.16$ & 3.28 \\
\hline $\mathrm{HCB}$ & $83.79 \pm 9.01$ & 10.76 & $81.54 \pm 10.48$ & 12.86 & $86.46 \pm 3.95$ & 4.56 & $89.59 \pm 10.21$ & 12.11 \\
\hline$\beta-\mathrm{HCH}$ & $76.62 \pm 8.05$ & 10.50 & $81.90 \pm 9.57$ & 11.69 & $87.03 \pm 11.29$ & 12.97 & $113.92 \pm 15.44$ & 12.82 \\
\hline Aldrin & $85.36 \pm 10.96$ & 12.84 & $91.46 \pm 5.46$ & 5.97 & $91.56 \pm 4.48$ & 4.89 & $95.35 \pm 6.32$ & 6.14 \\
\hline Heptachlor & $81.82 \pm 3.76$ & 4.60 & $99.28 \pm 13.33$ & 13.43 & $98.70 \pm 5.81$ & 5.89 & $101.77 \pm 4.72$ & 4.69 \\
\hline o,p-DDE & $74.76 \pm 6.50$ & 8.69 & $88.78 \pm 9.01$ & 10.15 & $101.94 \pm 5.96$ & 5.85 & $102.03 \pm 5.74$ & 5.52 \\
\hline$\alpha$-Endosulfan & $75.97 \pm 11.96$ & 15.74 & $103.21 \pm 4.71$ & 4.56 & $105.01 \pm 11.43$ & 10.89 & $107.36 \pm 6.66$ & 6.55 \\
\hline $\mathrm{p}, \mathrm{p}-\mathrm{DDE}$ & $75.80 \pm 8.78$ & 11.24 & $97.98 \pm 12.76$ & 13.02 & $98.39 \pm 3.37$ & 3.43 & $105.96 \pm 2.56$ & 2.41 \\
\hline Dieldrin & $75.04 \pm 8.41$ & 11.58 & $93.01 \pm 9.88$ & 10.63 & $97.60 \pm 9.88$ & 10.12 & $107.25 \pm 11.90$ & 11.68 \\
\hline Endrin & $93.43 \pm 5.27$ & 5.64 & $95.68 \pm 8.22$ & 8.59 & $106.34 \pm 5.38$ & 5.06 & $107.07 \pm 5.56$ & 5.53 \\
\hline$\beta$-Endosulfan & $69.58 \pm 7.20$ & 10.35 & $95.76 \pm 10.04$ & 10.49 & $110.59 \pm 5.58$ & 4.86 & $112.74 \pm 1.34$ & 1.19 \\
\hline $\mathrm{p}, \mathrm{p}-\mathrm{DDD}$ & $82.78 \pm 8.87$ & 10.72 & $98.45 \pm 5.26$ & 5.35 & $99.44 \pm 8.06$ & 8.11 & $102.56 \pm 8.23$ & 8.02 \\
\hline o,p-DDT & $103.71 \pm 8.62$ & 8.31 & $100.40 \pm 11.27$ & 11.23 & $101.04 \pm 6.55$ & 6.48 & $102.95 \pm 5.54$ & 4.90 \\
\hline p,p-DDT & $76.39 \pm 13.73$ & 17.97 & $89.66 \pm 7.54$ & 8.41 & $98.84 \pm 5.57$ & 5.64 & $98.36 \pm 12.82$ & 13.03 \\
\hline
\end{tabular}

TABLE 2: Linearity, LODs, and LOQs of OCPS after SPME procedure.

\begin{tabular}{|c|c|c|c|c|}
\hline & Equation & Correlation coefficient & $\mathrm{LOD}\left(\mathrm{ng} \mathrm{g}^{-1}\right)$ & LOQ $\left(\mathrm{ng} \mathrm{g}^{-1}\right)$ \\
\hline$\alpha-\mathrm{HCH}$ & $y=0.168-0.7642$ & 0.9906 & $1.00 \pm 0.33$ & $3.35 \pm 0.33$ \\
\hline $\mathrm{HCB}$ & $y=0.0866+0.3576$ & 0.9985 & $1.44 \pm 0.48$ & $4.80 \pm 0.48$ \\
\hline$\beta-\mathrm{HCH}$ & $y=0.0111-0.0155$ & 0.9933 & $1.50 \pm 0.50$ & $4.99 \pm 0.50$ \\
\hline Aldrin & $y=0.1025-0.1005$ & 0.9971 & $0.49 \pm 0.16$ & $1.62 \pm 0.16$ \\
\hline Heptachlor epoxide & $y=0.06-0.1873$ & 0.9970 & $0.73 \pm 0.24$ & $2.43 \pm 0.24$ \\
\hline o,p-DDE & $y=0.0147-0.0314$ & 0.9978 & $0.76 \pm 0.25$ & $2.53 \pm 0.25$ \\
\hline$\alpha$-Endosulfan & $y=0.0289-0.053$ & 0.9967 & $0.99 \pm 0.32$ & $3.30 \pm 0.32$ \\
\hline $\mathrm{p}, \mathrm{p}-\mathrm{DDE}$ & $y=0.0197-0.0206$ & 0.9978 & $1.34 \pm 0.45$ & $4.46 \pm 0.45$ \\
\hline Dieldrin & $y=0.0234-0.0452$ & 0.9963 & $1.20 \pm 0.40$ & $4.01 \pm 0.40$ \\
\hline Endrin & $y=0.0364-0.1672$ & 0.9900 & $0.60 \pm 0.20$ & $2.00 \pm 0.20$ \\
\hline$\beta$-Endosulfan & $y=0.0087+0.011$ & 0.9983 & $1.32 \pm 0.44$ & $4.41 \pm 0.44$ \\
\hline $\mathrm{p}, \mathrm{p}-\mathrm{DDD}$ & $y=0.0105-0.0202$ & 0.9971 & $0.78 \pm 0.25$ & $2.59 \pm 0.25$ \\
\hline o,p-DDT & $y=0.0298-0.1573$ & 0.9919 & $0.48 \pm 0.16$ & $1.61 \pm 0.16$ \\
\hline $\mathrm{p}, \mathrm{p}-\mathrm{DDT}$ & $y=0.0101-0.0232$ & 0.9975 & $1.19 \pm 0.40$ & $3.98 \pm 0.40$ \\
\hline
\end{tabular}

limits (MDLs), which can be regarded as LODs not instrument detection limits (IDLs). The LODs ranged from 0.48 to $1.50 \mathrm{ng} \mathrm{g}^{-1}$ after SPME analysis, with a $65 \mu \mathrm{m}$ PDMS/DVB fiber, whilst the LOQs ranged from 1.61 to $4.80 \mathrm{ng} \mathrm{g}^{-1}$. The results were in agreement with results found by Obuseng and coworkers, who indicated detection limits to be ranging from 0.266 to $1.693 \mu \mathrm{g} \mathrm{L}^{-1}$ when SPME was used for the determination of 7 OCPs (i.e., aldrin, endosulfan, p,p-DDD, DDE, dieldrin, endrin, and p,p-DDT) in Nymphaea nouchali roots [16]. However, some researchers achieved lower detection limits with SPME method; for instance, in fish tissues low detection limits ranging from 0.1 to $0.7 \mathrm{ng} \mathrm{g}^{-1}$ were obtained using SPME and GC-ECD [49]. Low detection limits (0.06 to $0.65 \mathrm{ng} \mathrm{g}^{-1}$ ) were also found when determining 18 OCPs in soil using SPME [33]. Detection limits may vary depending on several factors such as type of the matrix, fiber type, instrument type, and condition. Pérez-Trujillo [51] found different LODs for the same compound when using different SPME fibers in extraction of OCPs. The results indicated that LODs varied from 0.6 to $10.2 \mathrm{ng} \mathrm{L}^{-1}$ for the carbowaxdivinylbenzene (CW-DVB) fiber, from 0.5 to $11.6 \mathrm{ng} \mathrm{L}^{-1}$ for the carboxen-polydimethylsiloxane (CAR-PDMS) fiber, and from 0.4 to $7.4 \mathrm{ng} \mathrm{L}^{-1}$ for the divinylbenzene-carboxenpolydimethylsiloxane (DVB-CAR-PDMS) fiber [51]. Most OCPs have indicated low detection limits with $100 \mu \mathrm{m}$ PDMS fiber, which is sensitive for nonpolar compounds such as o,p-DDE, $\alpha$-endosulfan, p,p-DDE, dieldrin, endrin, $\beta$ endosulfan, p,p-DDD, o,p-DDT, and p,p-DDT $[33,48,52]$.

3.2.5. Analysis of Real Samples. SPME optimal conditions (i.e., extraction temperature, $90^{\circ} \mathrm{C}$; extraction time, $40 \mathrm{~min}$; phase ratio, $1: 1$; volume of water, $5 \mathrm{~mL}$; and desorption time, 


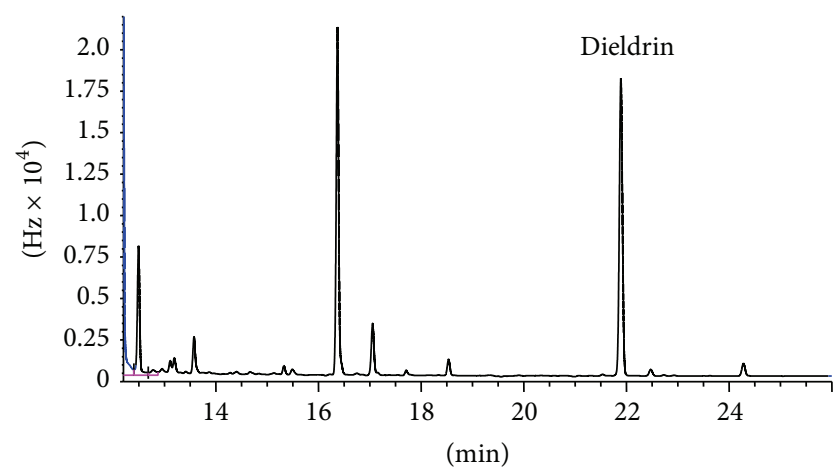

FIgURE 7: Terminalia sericea (B) after HS-SPME-GC-ECD analysis.

$5 \mathrm{~min}$ ) were applied to the roots of real samples, which are Pterocarpus angolensis, Maerua angolensis, Terminalia sericea, Cassia abbreviata, and Gymnosporia senegalensis. Only dieldrin was confirmed with MS and its concentration was found to be $150.5 \pm 8.4 \mathrm{ng} \mathrm{g}^{-1}$ in Terminalia sericea $B$ with ECD (Figure 7). However, some low levels of pesticides were detected with ECD in other plants, but these results could not be reliably confirmed since MS could not confirm the peaks due to high detection limits for the compounds of interest in MS as compared to ECD.

In Botswana, dieldrin was used in $1964[53,54]$ to control tsetse fly and mosquitoes in the areas of Okavango Delta and Kasane. Dieldrin has not been documented in any case from previous studies in Botswana. Since more studies about pesticides have been focused on the region of Okavango Delta, there is a need to look into the region of Kasane since pesticides were also applied in that region. Studies have also shown that aldrin can readily undergo oxidation to its more persistent epoxide, dieldrin [55]. The World Health Organization established the acceptable daily intake (ADI) of dieldrin as $100 \mathrm{ng} \mathrm{kg}^{-1}$ body weight and the oral reference dose (RfD) as $50 \mathrm{ng} \mathrm{kg}^{-1} \mathrm{day}^{-1}$ [56]. The EU maximum residue levels (MRLs) in milk are reported to be $6 \mathrm{ng} \mathrm{g}^{-1}$ [32], which is much less than what was detected in the sample. The high levels of dieldrin detected in Terminalia sericea B can possibly be explained by its persistence in the environment. Estimated half-life of dieldrin in the environment has been reported to be up to 25 years $[56,57]$.

\section{Conclusion}

Solid phase microextraction method for the analysis of OCPs in solid plants samples was successfully developed. HS-SPME combined with GC-ECD has been shown to be simple, fast (less steps), cheap, solventless, reproducible, and effective for the analysis of OCPs in medicinal plants. High recoveries in the range of $69.58 \pm 7.20$ to $113.92 \pm 15.44 \%$ were attained. Optimisation of parameters also yielded low LODs (lower than $2 \mathrm{ng} \mathrm{g}^{-1}$ ), high precision of the method, and good linearity $\left(R^{2} \geq 0.99\right)$. LODs ranged from 0.48 to $1.50 \mathrm{ng} \mathrm{g}^{-1}$, and the RSDs were found to be below $20 \%$ for all pesticides. Only dieldrin was detected in the roots of
Terminalia sericea species obtained from Kasane; however, the quality of medicinal plants in terms of pesticides was satisfactory since none were detected in most of them.

\section{Competing Interests}

The authors declare that they have no competing interests.

\section{References}

[1] N. R. Farnsworth, O. Akerele, A. S. Bingel, D. D. Soejarto, and Z. Guo, "Medicinal plants in therapy," Bulletin of the World Health Organization, vol. 63, no. 6, pp. 965-981, 1985.

[2] M. P. Setshogo and C. M. Mbereki, "Floristic diversity and uses of medicinal plants sold by street vendors in Gaborone, Botswana," The African Journal of Plant Science and Biotechnology, vol. 5, no. 1, pp. 69-74, 2011.

[3] C. W. Huie, "A review of modern sample-preparation techniques for the extraction and analysis of medicinal plants," Analytical and Bioanalytical Chemistry, vol. 373, no. 1-2, pp. 2330, 2002.

[4] WHO, WHO Traditional Medicine Strategy 2002-2005, World Health Organization, Geneva, Switzerland, 2002.

[5] A. Aquino, K. A. Wanderley, C. D. O. Paiva-Santos et al., "Coordination polymer adsorbent for matrix solid-phase dispersion extraction of pesticides during analysis of dehydrated Hyptis pectinata medicinal plant by GC/MS," Talanta, vol. 83 , no. 2 , pp. 631-636, 2010.

[6] L. B. Rivera-Rodríguez, R. Rodríguez-Estrella, J. J. Ellington, and J. J. Evans, "Quantification of low levels of organochlorine pesticides using small volumes $(\leq 100 \mu \mathrm{l})$ of plasma of wild birds through gas chromatography negative chemical ionization mass spectrometry," Environmental Pollution, vol. 148, no. 2, pp. 654662, 2007.

[7] H. Okatch, B. Ngwenya, K. M. Raletamo, and K. AndraeMarobela, "Determination of potentially toxic heavy metals in traditionally used medicinal plants for HIV/AIDS opportunistic infections in Ngamiland District in Northern Botswana," Analytica Chimica Acta, vol. 730, pp. 42-48, 2012.

[8] M. L. H. Mabaso, B. Sharp, and C. Lengeler, "Historical review of malarial control in southern African with emphasis on the use of indoor residual house-spraying," Tropical Medicine \& International Health, vol. 9, no. 8, pp. 846-856, 2004.

[9] M.-S. Kim, T. W. Kang, H. Pyo, J. Yoon, K. Choi, and J. Hong, "Determination of organochlorine pesticides in sediment using graphitized carbon black solid-phase extraction and gas chromatography/mass spectrometry," Journal of Chromatography A, vol. 1208, no. 1-2, pp. 25-33, 2008.

[10] A. O. Barakat, M. Mohammed Khairy, and I. Aukaily, "Persistent organochlorine pesticide and PCB residues in surface sediments of Lake Qarun, a protected area of Egypt," Chemosphere, vol. 90, pp. 2467-2476, 2013.

[11] N. S. Quinete, E. D. S. De Oliveira, D. R. Fernandes, A. D. S. Avelar, and R. E. Santelli, "Assessment of organochlorine pesticide residues in Atlantic Rain Forest fragments, Rio de Janeiro, Brazil," Environmental Pollution, vol. 159, no. 12, pp. 3604-3612, 2011.

[12] Stockholm Convention, "The Nine New POPs under the Stockholm Convention," 2009, http://chm.pops.int/Programmes/ NewPOPs/The9newPOPs/tabid/672/language/en-US/Default .aspx. 
[13] V. Pardío, D. Martínez, A. Flores et al., "Human health risk of dietary intake of organochlorine pesticide residues in bovine meat and tissues from Veracruz, México," Food Chemistry, vol. 135, no. 3, pp. 1873-1893, 2012.

[14] L. C. Mmualefe, N. Torto, P. Huntsman-Mapila, and B. Mbongwe, "Headspace solid phase microextraction in the determination of pesticides in water samples from the Okavango Delta with gas chromatography-electron capture detection and time-of-flight mass spectrometry," Microchemical Journal, vol. 91, no. 2, pp. 239-244, 2009.

[15] L. C. Mmualefe, N. Torto, P. Huntsman-Mapila, and B. Mbongwe, "Supercritical fluid extraction of pesticides in sediment from the Okavango Delta, Botswana, and determination by gas chromatography with electron capture detection (GCECD) and mass spectrometry (GC-MS)," Water SA, vol. 34, no. 3, pp. 405-410, 2008.

[16] V. C. Obuseng, B. M. Mookantsa, H. Okatch, K. Mosepele, and N. Torto, "Extraction of pesticides from plants using solid phase microextraction and QuEChERS," South African Journal of Chemistry, vol. 66, pp. 183-188, 2013.

[17] J. G. Martins, A. Amaya Chávez, S. M. Waliszewski, A. Colín Cruz, and M. M. García Fabila, "Extraction and clean-up methods for organochlorine pesticides determination in milk," Chemosphere, vol. 92, no. 3, pp. 233-246, 2013.

[18] A. Wilkowska and M. Biziuk, "Determination of pesticide residues in food matrices using the QuEChERS methodology," Food Chemistry, vol. 125, no. 3, pp. 803-812, 2011.

[19] H. Kataoka, H. L. Lord, and J. Pawliszyn, "Applications of solidphase microextraction in food analysis," Journal of Chromatography $A$, vol. 880, no. 1-2, pp. 35-62, 2000.

[20] Q. Guo, X. Lv, L. Tan, and B.-Y. Yu, "Simultaneous determination of 26 pesticide residues in 5 Chinese medicinal materials using solid-phase extraction and GC-ECD method," Chinese Journal of Natural Medicines, vol. 7, no. 3, pp. 210-216, 2009.

[21] L. Chen, F. Song, Z. Liu, Z. Zheng, J. Xing, and S. Liu, "Multiresidue method for fast determination of pesticide residues in plants used in traditional chinese medicine by ultra-highperformance liquid chromatography coupled to tandem mass spectrometry," Journal of Chromatography A, vol. 1225, pp. 132140, 2012.

[22] V. G. Zuin, J. H. Yariwake, and C. Bicchi, "Fast supercritical fluid extraction and high-resolution gas chromatography with electron-capture and flame photometric detection for multiresidue screening of organochlorine and organophosphorus pesticides in Brazil's medicinal plants," Journal of Chromatography A, vol. 985, no. 1-2, pp. 159-166, 2003.

[23] B. Łozowicka, M. Jankowska, E. Rutkowska, I. Hrynko, P. Kaczyński, and J. Miciński, "The evaluation of a fast and simple pesticide multiresidue method in various herbs by gas chromatography," Journal of Natural Medicines, vol. 68, no. 1, pp. 95-111, 2014.

[24] M. Barriada-Pereira, M. J. González-Castro, S. MuniateguiLorenzo, P. López-Mahía, D. Prada-Rodríguez, and E. Fernández-Fernández, "Comparison of pressurized liquid extraction and microwave assisted extraction for the determination of organochlorine pesticides in vegetables," Talanta, vol. 71, no. 3, pp. 1345-1351, 2007.

[25] G. A. D. Silva, F. Augusto, and R. J. Poppi, "Simultaneous optimization by neuro-genetic approach of a multiresidue method for determination of pesticides in Passiflora alata infuses using headspace solid phase microextraction and gas chromatography," Journal of Chromatography A, vol. 1138, no. 1-2, pp. 251-261, 2007.

[26] G. A. Gómez-Ríos and J. Pawliszyn, "Solid phase microextraction (SPME)-transmission mode (TM) pushes down detection limits in direct analysis in real time (DART)," Chemical Communications, vol. 50, no. 85, pp. 12937-12940, 2014.

[27] N. Sauret-Szczepanski, P. Mirabel, and H. Wortham, "Development of an SPME-GC-MS/MS method for the determination of pesticides in rainwater: laboratory and field experiments," Environmental Pollution, vol. 139, no. 1, pp. 133-142, 2006.

[28] E. Beceiro-González, E. Concha-Graña, A. Guimaraes, C. Gonçalves, S. Muniategui-Lorenzo, and M. F. Alpendurada, "Optimisation and validation of a solid-phase microextraction method for simultaneous determination of different types of pesticides in water by gas chromatography-mass spectrometry," Journal of Chromatography A, vol. 1141, no. 2, pp. 165-173, 2007.

[29] J. Merib, V. Simão, A. N. Dias, and E. Carasek, "Simultaneous determination of trihalomethanes and organochlorine pesticides in water samples by direct immersion-headspace-solid phase microextraction," Journal of Chromatography A, vol. 1321, pp. 30-37, 2013.

[30] J. L. R. Júnior and N. Ré-Poppi, "Determination of organochlorine pesticides in ground water samples using solidphase microextraction by gas chromatography-electron capture detection," Talanta, vol. 72, no. 5, pp. 1833-1841, 2007.

[31] D. A. Lambropoulou, V. A. Sakkas, D. G. Hela, and T. A. Albanis, "Application of solid-phase microextraction in the monitoring of priority pesticides in the Kalamas River (N.W. Greece)," Journal of Chromatography A, vol. 963, no. 1-2, pp. 107-116, 2002.

[32] M. Fernandez-Alvarez, M. Llompart, J. P. Lamas et al., "Development of a solid-phase microextraction gas chromatography with microelectron-capture detection method for a multiresidue analysis of pesticides in bovine milk," Analytica Chimica Acta, vol. 617, no. 1-2, pp. 37-50, 2008.

[33] R.-A. Doong and P.-L. Liao, "Determination of organochlorine pesticides and their metabolites in soil samples using headspace solid-phase microextraction," Journal of Chromatography A, vol. 918, no. 1, pp. 177-188, 2001.

[34] M. Fernandez-Alvarez, M. Llompart, J. Pablo Lamas et al., "Simultaneous determination of traces of pyrethroids, organochlorines and other main plant protection agents in agricultural soils by headspace solid-phase microextractiongas chromatography," Journal of Chromatography A, vol. 1188, no. 2, pp. 154-163, 2008.

[35] M. K. Chai and G. H. Tan, "Validation of a headspace solidphase microextraction procedure with gas chromatographyelectron capture detection of pesticide residues in fruits and vegetables," Food Chemistry, vol. 117, no. 3, pp. 561-567, 2009.

[36] C. M. Kin and T. G. Huat, "Headspace solid-phase microextraction for the evaluation of pesticide residue contents in cucumber and strawberry after washing treatment," Food Chemistry, vol. 123, no. 3, pp. 760-764, 2010.

[37] J. Zeng, J. Chen, Z. Lin, W. Chen, X. Chen, and X. Wang, "Development of polymethylphenylsiloxane-coated fiber for solidphase microextraction and its analytical application of qualitative and semi-quantitative of organochlorine and pyrethroid pesticides in vegetables," Analytica Chimica Acta, vol. 619, no. 1, pp. 59-66, 2008.

[38] L. B. A. T. Abdulra'uf and G. H. Tan, "Multivariate study of parameters in the determination of pesticide residues in apple by headspace solid phase microextraction coupled to 
gas chromatography-mass spectrometry using experimental factorial design," Food Chemistry, vol. 141, no. 4, pp. 4344-4348, 2013.

[39] D. A. Lambropoulou and T. A. Albanis, "Headspace solid phase microextraction applied to the analysis of organophosphorus insecticides in strawberry and cherry juices," Journal of Agricultural and Food Chemistry, vol. 50, no. 12, pp. 3359-3365, 2002.

[40] W.-H. Ho and S.-J. Hsieh, "Solid phase microextraction associated with microwave assisted extraction of organochlorine pesticides in medicinal plants," Analytica Chimica Acta, vol. 428, no. 1, pp. 111-120, 2001.

[41] B.-H. Hwang and M.-R. Lee, "Solid-phase microextraction for organochlorine pesticide residues analysis in Chinese herbal formulations," Journal of Chromatography A, vol. 898, no. 2, pp. 245-256, 2000.

[42] N. Campillo, R. Peñalver, and M. Hernández-Córdoba, "Pesticide analysis in herbal infusions by solid-phase microextraction and gas chromatography with atomic emission detection," Talanta, vol. 71, no. 3, pp. 1417-1423, 2007.

[43] L. Cai, J. Xing, L. Dong, and C. Wu, "Application of polyphenylmethylsiloxane coated fiber for solid-phase microextraction combined with microwave-assisted extraction for the determination of organochlorine pesticides in Chinese teas," Journal of Chromatography A, vol. 1015, no. 1-2, pp. 11-21, 2003.

[44] J. Schurek, T. Portolés, J. Hajslova, K. Riddellova, and F. Hernández, "Application of head-space solid-phase microextraction coupled to comprehensive two-dimensional gas chromatography-time-of-flight mass spectrometry for the determination of multiple pesticide residues in tea samples," Analytica Chimica Acta, vol. 611, no. 2, pp. 163-172, 2008.

[45] A. Achouri, J. I. Boye, and Y. Zamani, "Identification of volatile compounds in soymilk using solid-phase microextraction-gas chromatography," Food Chemistry, vol. 99, no. 4, pp. 759-766, 2006.

[46] M. De Fátima Alpendurada, "Solid-phase microextraction: a promising technique for sample preparation in environmental analysis," Journal of Chromatography A, vol. 889, no. 1-2, pp. 3$14,2000$.

[47] Y. Naudé and E. R. Rohwer, "Two multidimensional chromatographic methods for enantiomeric analysis of o, $\mathrm{p}^{\prime}$-DDT and $o, \mathrm{p}^{\prime}$-DDD in contaminated soil and air in a malaria area of South Africa," Analytica Chimica Acta, vol. 730, pp. 120-126, 2012.

[48] J. Cai, F. Zhu, W. Ruan et al., "Determination of organochlorine pesticides in textiles using solid-phase microextraction with gas chromatography-mass spectrometry," Microchemical Journal, vol. 110, pp. 280-284, 2013.

[49] N. Fidalgo-Used, G. Centineo, E. Blanco-González, and A. Sanz-Medel, "Solid-phase microextraction as a clean-up and preconcentration procedure for organochlorine pesticides determination in fish tissue by gas chromatography with electron capture detection," Journal of Chromatography A, vol. 1017, no. 1-2, pp. 35-44, 2003.

[50] A. N. Dias, V. Simão, J. Merib, and E. Carasek, "Use of green coating (cork) in solid-phase microextraction for the determination of organochlorine pesticides in water by gas chromatography-electron capture detection," Talanta, vol. 134, pp. 409-414, 2015.

[51] J. P. Pérez-Trujillo, S. Frías, J. E. Conde, and M. A. RodríguezDelgado, "Comparison of different coatings in solid-phase microextraction for the determination of organochlorine pesticides in ground water," Journal of Chromatography A, vol. 963, no. 1-2, pp. 95-105, 2002.

[52] P. N. Carvalho, P. N. R. Rodrigues, F. Alves, R. Evangelista, M. C. P. Basto, and M. T. S. D. Vasconcelos, "An expeditious method for the determination of organochlorine pesticides residues in estuarine sediments using microwave assisted pre-extraction and automated headspace solid-phase microextraction coupled to gas chromatography-mass spectrometry," Talanta, vol. 76, no. 5, pp. 1124-1129, 2008.

[53] P. S. Daka, V. C. Obuseng, N. Torto, and P. Huntsman-Mapila, "Deltamethrin in sediment samples of the Okavango Delta, Botswana," Water SA, vol. 32, no. 4, pp. 483-488, 2006.

[54] P. M. Kgori, S. Modo, and S. J. Torr, “The use of aerial spraying to eliminate tsetse from the Okavango Delta of Botswana," Acta Tropica, vol. 99, no. 2-3, pp. 184-199, 2006.

[55] D. E. Stevenson, E. F. Walborg Jr., D. W. North et al., "Monograph: reassessment of human cancer risk of aldrin/dieldrin," Toxicology Letters, vol. 109, no. 3, pp. 123-186, 1999.

[56] A. G. Kanthasamy, M. Kitazawa, A. Kanthasamy, and V. Anantharam, "Dieldrin-induced neurotoxicity: relevance to Parkinson's disease pathogenesis," NeuroToxicology, vol. 26, no. 4, pp. 701-719, 2005.

[57] S. N. Meijer, C. J. Halsall, T. Harner et al., "Organochlorine pesticide residues in archived UK soil," Environmental Science and Technology, vol. 35, no. 10, pp. 1989-1995, 2001. 

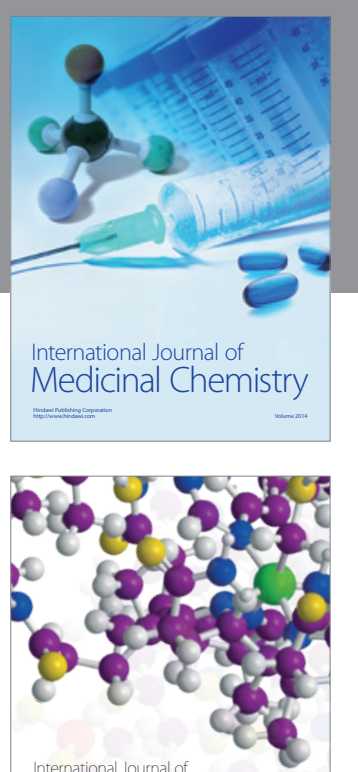

Carbohydrate Chemistry

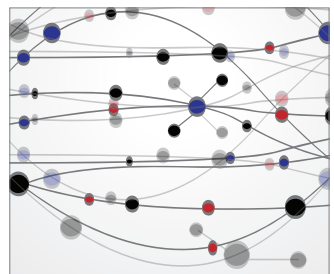

The Scientific World Journal
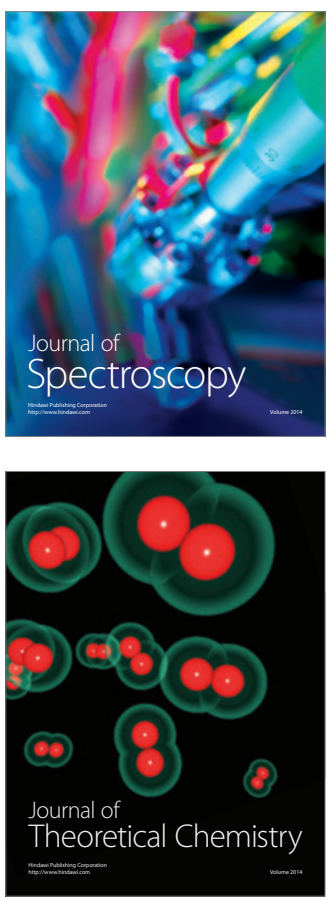
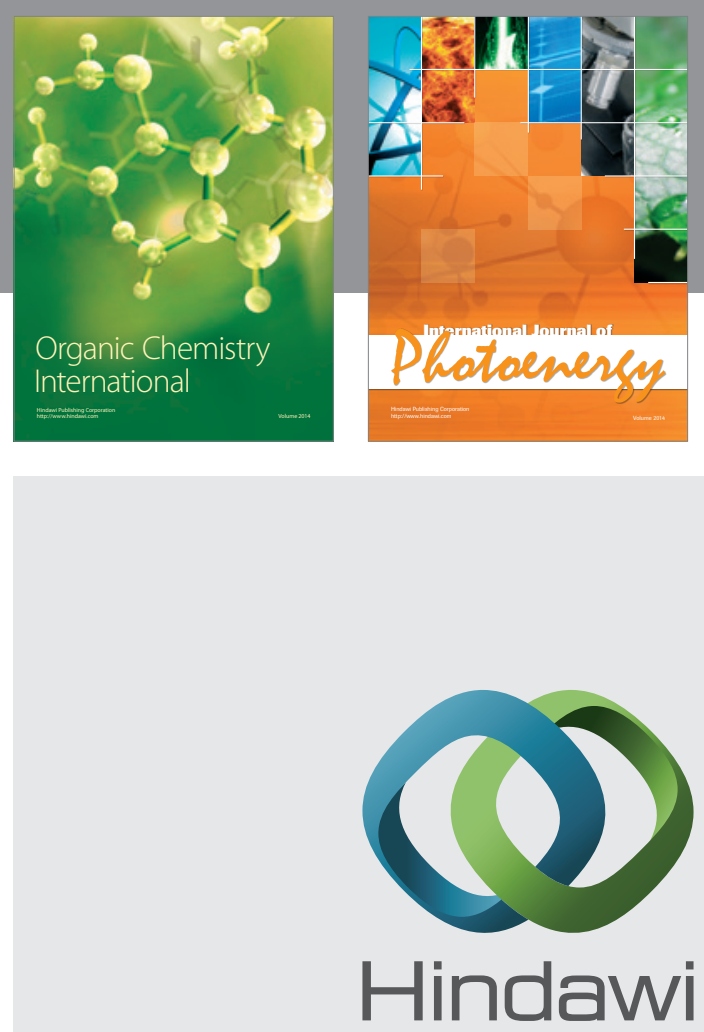

Submit your manuscripts at

http://www.hindawi.com

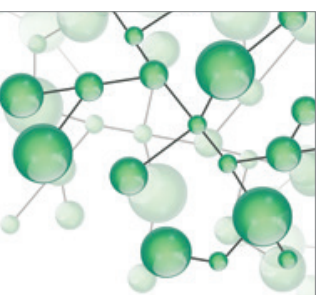

International Journal of

Inorganic Chemistry

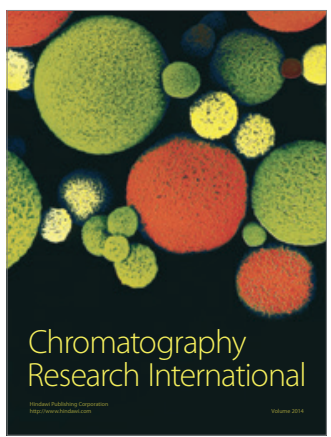

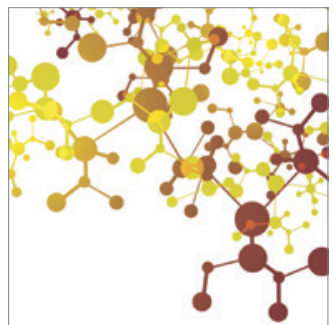

Applied Chemistry
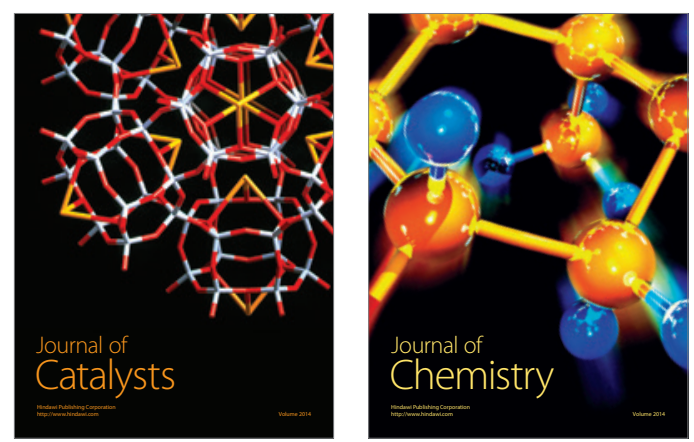
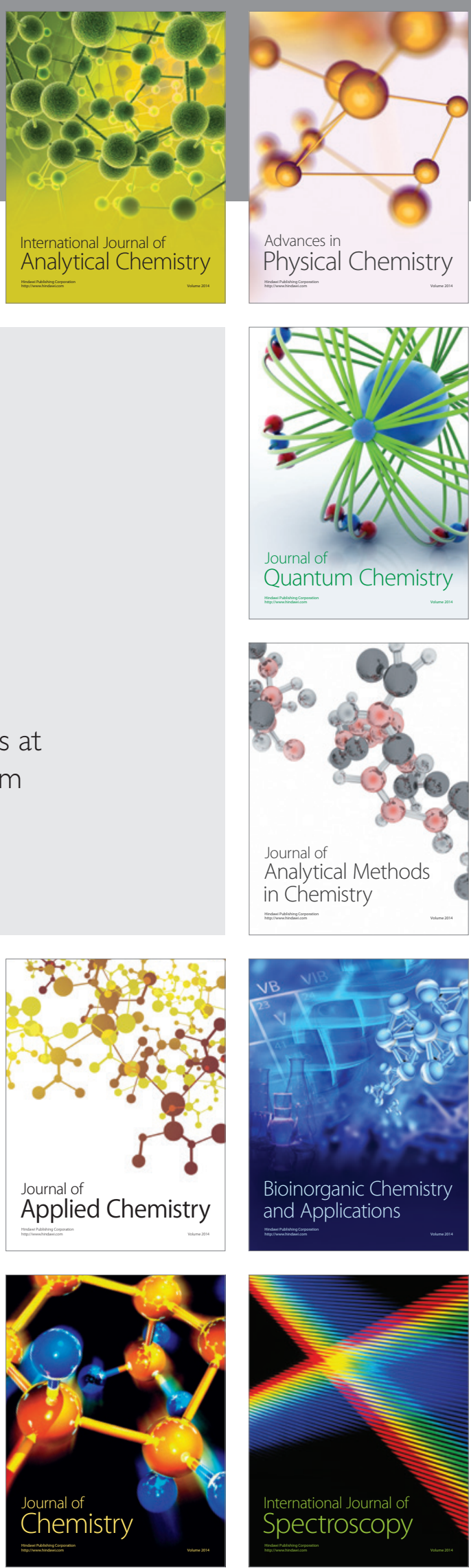